Original article

\title{
SEROLOGICAL SURVEY FOR AVIAN INFLUENZA VIRUS INFECTION OF BACKYARD POULTRY AND POULTRY WORKERS IN BAGHDAD AND BASRAH PROVINCES, IRAQ
}

\author{
S. I. JABER ${ }^{1} \&$ H. T. THWINY ${ }^{2}$ \\ ${ }^{1}$ College of Medical Technology, Technical University of the Central Region, \\ Baghdad, Iraq; ${ }^{2}$ Department of Microbiology, College of Veterinary Medi- \\ cine, University of Basrah, Basrah, Iraq
}

\begin{abstract}
Summary
Jaber, S. I. \& H. T. Thwiny, 2020. Serological survey for avian influenza virus infection of backyard poultry and poultry workers in Baghdad and Basrah provinces, Iraq. Bulg. J. Vet. Med., 23, No 2, 187-196.

The aim of this study was to determine the prevalence of avian influenza virus (AIV) subtype H5N1 among backyard birds and poultry workers. The study included backyard birds (chickens and ducks) in rural areas of Baghdad and Basrah provinces, Iraq. Rural areas were divided into wet land and dry land. Total egg samples were 368, divided into 184 eggs ( 92 chicken eggs and 92 duck eggs) from each province. The total number of human sera was 180 (45 poultry worker and 45 non-poultry worker samples from each province). Competitive ELISA tests were used for detection of specific antibodies against influenza A virus and influenza subtype H5N1 in all samples. Seroprevalence against AIV type A in chickens was $62.5 \%$ (115/184) while ducks showed seroprevalence of $40.8 \%$ (75/184). The seropositivity among the backyard birds in wet land rural areas was higher than that in dry land rural areas. The samples positive for subtype H5N1 in chickens were 15.7\% (18/115) while in ducks: $12 \%(9 / 75)$ with highest seropositivity among chickens in wet land rural areas $(18.8 \%$; 12/64). The seropositivity of avian influenza H5N1 was 6\% (4/67) among AIV-positive poultry workers and $2.9 \%(1 / 34)$ among non-poultry workers.
\end{abstract}

Key words: AIV, backyard birds, Iraq

\section{INTRODUCTION}

Influenza virus is enveloped, has negativestrand RNA, belongs to the family Orthomyxoviridae, and has four types: A, B, C and D. Type A is further subdivided into subtypes based upon surface viral proteins haemagglutinin $(\mathrm{H})$ and neuraminidase (N). Birds are infected only by influenza virus type A. Currently, $16 \mathrm{H}$ and $9 \mathrm{~N}$ virus subtypes have been described in avian species, and avian influenza viruses (AIVs) with various subtype combinations have been isolated (Capua \& Marangon, 2007). AIVs are further classified into two distinct groups, high pathogenic avian 
influenza (HPAI) viruses and low pathogenic avian influenza (LPAI) viruses, based on their ability to produce clinical disease in chickens (Capua et al., 2000; Kiss et al., 2008). The subtype HPAI $\mathrm{H} 5 \mathrm{~N} 1$ virus is considered the major challenge for both veterinary and human public health. Most H5N1 HPAI virus outbreaks have occurred in domestic poultry, either backyard or in small commercial farms, indicative of the high incidence rate among these species (FAO, 2011). Although H5N1 HPAI viruses have not acquired efficient transmission among people, direct viral transmission from poultry to humans has caused severe disease and death (WHO, 2015).

The threat of an influenza pandemic remains real. Outbreaks of avian $\mathrm{H} 5 \mathrm{~N} 1$ influenza viruses continue to occur among birds and humans in many areas of the world (Monto \& Whitley, 2008). From February 2006 to March 2007, infections due to H5N1 HPAI virus were reported in five Middle Eastern countries, namely: Iraq, Kuwait, Jordan, Palestine and Kingdom of Saudi Arabia (WHO, 2008). Migrating wild waterfowl are assumed to represent a risk for the transmission of infectious diseases to domestic poultry and humans. Generally, migratory waterfowl spread avian influenza virus (AIV) without showing any clinical signs of disease (Webster et al., 2006). During winter (from December through February), marshes and swamps in south and middle Iraq are shared by large number of migratory waterfowl and domestic birds. As a result, the backyard birds might get AIVs from migratory waterfowl which act as a natural reservoir of AIVs without showing any clinical disease. Waterfowl is a source of LPAI viruses for domestic avian populations (Fouchier \& Munster, 2009), in which they can evolve into HPAI strains
(Abolnik et al., 2007). Therefore, domestic poultry may play a major role in the ecology of AIVs and may act as potential vessels for their genetic reassortment and thus demand active surveillance. Previous studies have demonstrated that both direct and indirect exposure to infected poultry plays a very important role in the transmission of AIVs to humans (Koopmans et al., 2004; Dinh et al., 2006; Zhou et al., 2009). Poultry workers in direct contact with domestic fowl are recognised as the front line of transmission of AIVs to humans, which has been shown in studies of H5N1 viruses in Asia and Europe (Gray \& Kayali, 2009; Leibler et al., 2009). Poultry workers are therefore considered to be at high risk of infection with AIVs because of their frequent exposure to chickens. As influenza H5N1 viruses continue to circulate and evolve among poultry, poultry-to-human transmission of $\mathrm{H} 5 \mathrm{~N} 1$ viruses could increase. Therefore, the extent of asymptomatic and clinically mild illness among humans that is caused by circulating $\mathrm{H} 5 \mathrm{~N} 1$ virus strains should be monitored.

In this study, we sought to determine the prevalence of AIVs in backyard poultry, and to better understand the real infection rate of H5N1. It investigates the potential for the zoonotic spread to humans and evaluates the subclinical infection among poultry workers in Iraq.

\section{MATERIALS AND METHODS}

\section{Subjects and study design}

From November 2017 through April 2018, a cross-sectional study was conducted to survey antibodies against AIV in birds and humans. The study included backyard birds (chickens and ducks) in rural areas of Baghdad and Basrah provinces which are located in central and 
southern Iraq, respectively. Rural areas were classified into two types: wet land rural areas, near the marshes or swamps and dry land rural areas, far from marshes or swamps. In Baghdad province, the wet land rural areas included in this study were Fadalia, Thahab Abeaz Village and Kachia Village while the dry land rural areas were Madinat Al Sadar, Al Dora and Al Beaa. In Basrah province, the wet land rural areas were Mudina, Qurna and Karmat Ali while the dry land rural areas were Abo Alkasib, Zubair and Shat AL Arab. All backyard birds in Iraq were not vaccinated against AIV. The other part of the study included poultry workers (responsible for poultry feeding, cleaning, selling, slaughtering, veterinarians and vaccinators) and non-poultry workers. The workers were routinely, heavily exposed to chickens and expected to have the highest level of exposure to influenza virus-infected birds. The non-poultry workers were not in contact with birds as a control group. All participants in this study were not vaccinated against influenza. There were no exclusion criteria, except for those people who did not want to participate in this study.

\section{Sample collection}

Samples taken from birds were eggs while serum samples were collected from humans. The total number of eggs was 368 eggs which were divided into 184 eggs from Baghdad and 184 eggs from Basrah. Also, the 184 eggs of each province were divided into 92 eggs (46 duck eggs and 46 chicken eggs) purchased from wet land rural areas and the same number purchased from dry land rural areas. The human sera were 180 samples, divided into 90 samples from Baghdad and 90 samples from Basrah provinces. The 90 samples of each province were divided into 45 sam- ples from poultry workers and 45 samples from non-poultry workers.

\section{Sample preparation}

Preparation of egg yolk. Eggs were individually cracked and the egg yolk separated from the white. Under sterile conditions the yolk sac was ruptured with a needle and $2 \mathrm{~mL}$ of yolk was collected with a syringe. Then, the yolk was mixed with an equal volume of phosphatebuffered saline and homogenised. The mixture was shaken and mixed evenly, centrifuged at $3000 \times \mathrm{g}$ for $15 \mathrm{~min}$ (Spackman et al., 2009). The supernatant (1.5 $\mathrm{mL}$ ) was collected in Eppendorf tubes and stored at $-20^{\circ} \mathrm{C}$ until use.

Preparation of human serum. Five $\mathrm{mL}$ of whole venous blood was collected by sterile syringe from each subject. Blood samples were allowed to clot at room temperature for 15 to $30 \mathrm{~min}$, then separated by centrifugation and transferred to $1.5 \mathrm{~mL}$ Eppendorf tubes. Samples were stored at $-20^{\circ} \mathrm{C}$ until they were analysed.

\section{Serological assays}

Competitive enzyme linked immunosorbent assay (ELISA) was used for the detection of specific antibodies against influenza A virus in egg yolk using a commercial Avian Influenza Virus antibody ELISA kit (Shenzhen Lvshiyuan Biotechnology Co. Ltd, China). Another commercial ELISA kit (Influenza A IgG ELISA Immunolab $\mathrm{GmbH}$, Germany) was used for the detection of anti-nucleoprotein antibodies to AIV in human sera. The positive samples of egg yolk and serum were screened for detection of specific antibodies against subtype H5N1 of influenza $A$ virus by means of competitive ELISA kit (Avian Influenza H5N1 Virus Antibodies ELISA Kit; Elabscience Biotechnology Inc., USA). All the diagnostic 
kits were performed according to the manufacturers' instructions. ELISA reading was done using ELx800 ${ }^{\mathrm{TM}}$ Absorbance Microplate Reader (USA).

\section{Statistical analysis}

Differences between the different groups were analysed with the Chi-square test at the $\mathrm{P} \leq 0.05$ level (IBM SPSS, 2011).

\section{RESULTS}

The backyard chickens exhibited $62.5 \%$ $(115 / 184)$ seroprevalence against influenza virus type A while the backyard ducks - 40.8\% (75/184). This difference was significant $(\mathrm{P}<0.05)$. Chickens in wet land rural areas had a higher seropositivity compared to chickens in dry land rural areas, and the same was recorded in ducks. Basrah province recorded a higher seropositivity than Baghdad province (Table 1). The seropositivity among the backyard birds in wet land rural areas were $59.8 \%(110 / 184)$ while that of backyard birds in dry land rural areas was statistically significantly lower (43.5\%; $80 / 184$ ) (Table 1). The seropositivity rate against influenza virus type A was $74.4 \%$ (67/90) among poultry workers that was substantially higher compared to $37.7 \%$ (34/90) among non-poultry workers $(\mathrm{P}<0.05)$. Also, poultry workers and nonpoultry workers recorded higher seropositivity in Basrah province than in Baghdad province (Table 1). Backyard chickens showed $15.7 \%(18 / 115)$ seroprevalence against avian influenza virus subtype H5N1 while backyard ducks showed $12 \%$ (9/75). The highest seropositivity $(\mathrm{P}<0.05)$ against avian influenza subtype H5N1 was among backyard chicken in wet land rural areas: $18.8 \%(12 / 64)$.

In Baghdad province, the seropositivity against avian influenza subtype H5N1 was higher than in Basrah province (Table
2). The seropositivity against avian influenza H5N1 was 6\% (4/67) among poultry workers vs $2.9 \%$ (1/34) among nonpoultry workers. Baghdad province recorded higher seropositivity than Basrah province among poultry workers and nonpoultry workers but these differences were not significant (Table 2).

\section{DISCUSSION}

We chose egg yolk samples to detect antibodies against influenza A instead of serum samples because blood collection in birds has practical difficulties (Jeong et al., 2010). Other studies demonstrated that egg yolk is a good alternative source for the detection of antibodies of influenza viruses in chickens and ducks (Trampel et al., 2006; Jeong et al., 2010; Hotta et al., 2013). Competitive ELISA tests were used as they are very practical and suitable serological diagnostic tools in monitoring programs for avian influenza for different bird species and humans which can carry several AIV subtypes. Also, commercial competitive ELISA kits have a high sensitivity and specificity when compared with other serological diagnostic tools such as hemagglutination inhibition (HI) test (Starick et al., 2006).

The seroprevalence against influenza virus type A among backyard chicken was $62.5 \%$ while among backyard ducks was $40.8 \%$. This difference may be due to the greatest exposure of chickens to AIV than ducks, and/or ducks' lower antibody response compared to that of other avian species (Higgins, 1996). The difference in seroprevalence against influenza virus type A among different bird species was also reported in other studies (Wilson et al., 2013; Munyua et al., 2018). Our results showed that seroprevalence among backyard birds in wet land rural areas was higher (59.8\%) compared to dry land rural 


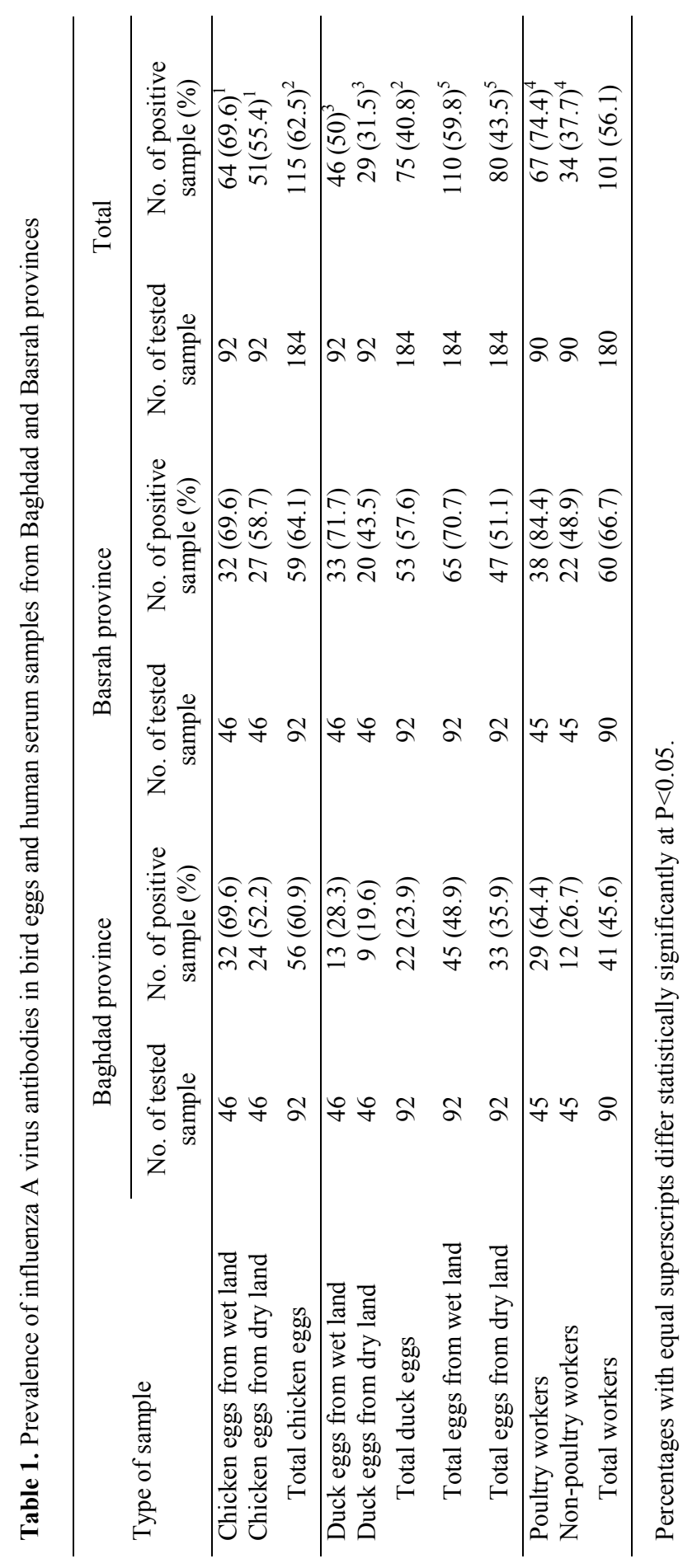

BJVM, 23, No 2 
Serological survey for avian influenza virus infection of backyard poultry and poultry workers in ...

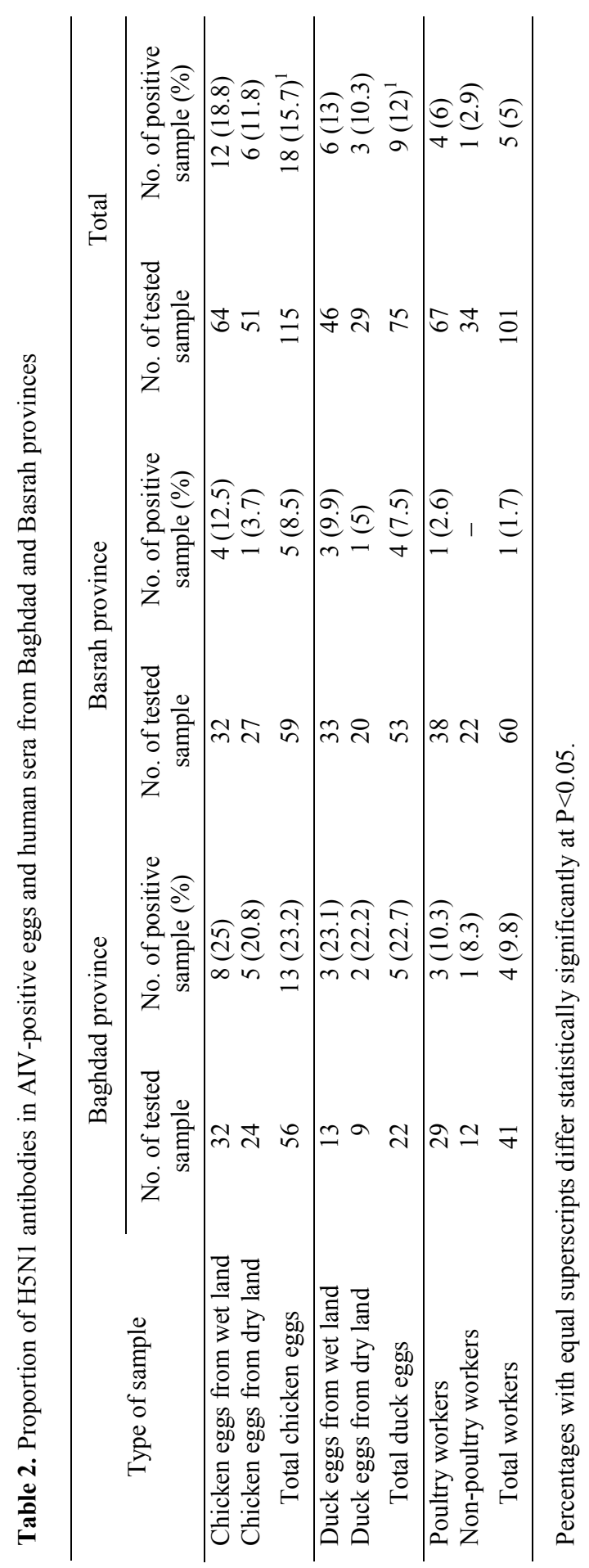


areas $(43.5 \%)$. This difference may be due to two reasons: first, during the winter months, marshes and swamps in wet land rural areas in our country are shared by a large number of migratory birds, that may carry AIV without showing any clinical signs of disease and spread it to backyard birds (Fouchier et al., 2009). Second, AIV is an enveloped virus therefore more sensitive to dryness. AIV remains active for a long time in wet environment as well as the water helps in AIV spread. This is also conmfirmed by other studies reporting that marine birds had a higher seroprevalence against influenza virus than terrestrial birds (Wilson et al., 2013). As seropositivity of AIV subtype H5N1 among chickens and ducks raised in wet or dry land was concerned, chickens recorded higher seropositivity than ducks and birds from wet land recorded higher seropositivity vs those from dry land (Table 2). Pittman et al. (2007) stated that specific antibodies against AIV subtype H5 were discovered in $16.3 \%$ of ducks. Saldan et al. (2006) discovered specific antibodies against AIV subtype $\mathrm{H} 5 \mathrm{~N} 1$ in $24 \%$ of examined blood serum samples of wild birds, while another study established specific antibodies against the AIV type A in $3.54 \%$ of all examined blood serum samples using ELISA. There was a difference in the seroprevalence of AIV type A and subtype $\mathrm{H} 5 \mathrm{~N} 1$ in chickens and ducks between different regions of Iraq (Tables 1 and 2). The Basrah province had the highest seroprevalence of AIV type A while Baghdad province had the highest seroprevalence of AIV subtype H5N1. The high AIV type A prevalence in Basrah province may be attributable to the marshes of Basrah receiving high populations of migratory wild waterfowl compared to Baghdad. These birds are a major natural reservoir of AIV (Olsen et al.,
2006). The high AIV subtype H5N1 prevalence in Baghdad province may be attributable to the presence of many commercial chicken flocks and during the previous years, outbreaks of AIV H5N1 occurred in these flocks (WHO, 2015). These regional differences were also reported in another study in Oman (Al Shekailia et al., 2015).

Depending on our results the probability of influenza virus infection among poultry workers was double when compared to non-poultry workers. Occupational exposure to infected poultry is an important factor in AIV transmission to humans (Schultsz et al., 2009). As H5N1 viruses continue to circulate and evolve among poultry, poultry-to-human transmission of $\mathrm{H} 5 \mathrm{~N} 1$ viruses could increase. According to our results, 6\% of AIVpositive workers had antibodies against subtype H5N1. Among people exposed to birds, the prevalence of H5N1 antibodies is in the range of $0-14.6 \%$ (Shortridge et al., 1998; Lu et al., 2007). Poultry workers in Asian countries, where there is endemic circulation of $\mathrm{A} / \mathrm{H} 5 \mathrm{~N} 1$, are constantly exposed to high levels of the virus. This transmission to humans results in mild or sub-clinical infections with seroconversions while acute infections is still rare (Horm et al., 2016). The H5N1 virus results in a systemic infection likely to produce a neutralising antibody response (Shortridge et al., 1998). On the grounds of obtained results, we concluded that chickens from wet land were the main reservoir of the AIV subtypes $\mathrm{H} 5 \mathrm{~N} 1$ and the individuals with occupational exposure to domestic poultry were at increased risk of infection with $\mathrm{H} 5 \mathrm{~N} 1$ virus than non-poultry workers. Occupational exposure to AIVs is an important public health measure due to the potential transformation of this animal virus into a novel virus 
that may be more easily transmitted from person to person. There is evidence that the human influenza virus in past pandemics could have acquired genes from avian viruses (Shortridge et al., 1998). Extensive investigations should be routinely conducted for all H5N1 outbreaks among humans and animals to monitor the nature and extent of bird-to-human or human-to-human transmission of $\mathrm{H} 5 \mathrm{~N} 1$ viruses. Additional seroepidemiologic investigations should be conducted to assess the ongoing risk for bird-to-human transmission of $\mathrm{H} 5 \mathrm{~N} 1$ among rural and other human populations.

\section{REFERENCES}

Abolnik, C., S. Bisschop, T. Gerdes, A. Olivier \& R. Horner, 2007. Outbreaks of avian influenza H6N2 viruses in chickens arose by a reassortment of $\mathrm{H} 6 \mathrm{~N} 8$ and H9N2 ostrich viruses. Virus Genes, 34, $37-45$.

Al Shekailia, T., H. Clougha, K. Ganapathya \& M. Baylis, 2015. Sero-surveillance and risk factors for avian influenza and Newcastledisease virus in backyard poultry in Oman. Preventive Veterinary Medicine, 122, 145-153.

Capua, I. \& S. Marangon, 2007. The use of vaccination to combat multiple introductions of Notifiable avian influenza viruses of the H5 and $\mathrm{H} 7$ subtypes between 2000 and 2006 in Italy. Vaccine, 25, 4987 4995.

Capua, I., B. Grossele, E. Bertoli \& P. Cordioli, 2000. Monitoring for highly pathogenic avian influenza in wild birds in Italy. The Veterinary Record, 147, 640.

Dinh, P. N., H. T. Long, N. T. Tien, N. T. Hien \& T. Q. Maile, 2006. Risk factors for human infection with avian influenza A H5N1, Vietnam, 2004. Emerging Infectious Diseases, 12, 1841-1847.

FAO, 2011. H5N1 HPAI global overview: October-December 2011. FAO website, http://www.fao.org/docrep/015/an336e/an 336e00.pdf (Date last accessed 11 February 2019).

Fouchier, R. A. M. \& V. J. Munster, 2009. Epidemiology of low pathogenic avian influenza viruses in wild birds. Revue Scientifique et Technique (International Office of Epizootics), 28, 49-58.

Gray, G. C. \& G. Kayali, 2009. Facing pandemic influenza threats: The importance of including poultry and swine workers in preparedness plans. Poulryt Science, 88, 880-884.

Higgins, D. A., 1996. Comparative immunology of avian species. In: Poultry Immunology, $24^{\text {th }}$ edn, eds T. F. Davison, T. R. Morris \& L. N. Payne, Abingdon, VA: Carfax Publishing Co., pp. 149-205.

Horm, S. V., A. Tarantola, S. Rith, S. Ly, J. Gambaretti, V. Duong, S. Sorn, D. Holl, L. Allal, W. Kalpravidh, P. Dussart, P. F. Horwood \& P. Buchy, 2016. Intense circulation of $\mathrm{A} / \mathrm{H} 5 \mathrm{~N} 1$ and other avian influenza viruses in Cambodian live-bird markets with serological evidence of subclinical human infections. Emerging $\mathrm{Mi}$ crobes \& Infections, 5, e70.

Hotta, K., H. Takakuwa, T. Yabuta, T. T. Ung, T. Usui, H. L. Nguyen, T. T. Le, M. Q. Le, T. Yamaguchi, K. Otsuki, T. Ito, T. Murase \& T. Yamashiro, 2013. Antibody survey on avian influenza viruses using egg yolks of ducks in Hanoi between 2010 and 2012. Veterinary Microbiology, 116, 179-183.

Jeong, O. M., M. C. Kim, H. M. Kang, G. W. Ha, J. S. Oh, J. E. Yoo, C. H. Park, J. S. Kwon, M. R. Pack, H. R. Kim, Y. J. Kim, J. H. Kwon \& Y. J. Lee, 2010. Validation of egg yolk antibody based CELISA for avian influenza surveillance in breeder duck. Veterinary Microbiology, 144, 287-292.

Kiss, I., P. Gyarmati, S. Zohari, K. W. Ramsay, G. Metreveli, E. Weiss, M. Brytting, M. Stivers, S. Lindstrom \& A. Lundkvist, 2008. Molecular characterization of highly pathogenic $\mathrm{H} 5 \mathrm{~N} 1$ avian influenza viruses 
isolated in Sweden in 2006. Virology Journal, 5, 113 .

Koopmans, M., B. Wilbrink, M. Conyn, G. Natrop \& H. van der Nat, 2004. Transmission of H7N7 avian influenza A virus to human beings during a large outbreak in commercial poultry farms in the Netherlands. Lancet, 363, 587-593.

Leibler, J. H., J. Otte, D. Roland-Holst, D. U. Pfeiffer, R. Soares Magalhaes, J. Rushton, J. P. Graham \& E. K. Silbergeld, 2009. Industrial food animal production and global health risks: exploring the ecosystems and economics of avian influenza. Ecohealth, 6, 58-70.

Lu, E., Y. Liu, Y. Chen, Y. Zhou \& L. Jiang, 2007. Analysis on Avian Influenza Surveillance in Occupational Population in Guangzhou in 2006. Journal of Tropical Medicine, 7, 923-924.

Monto, A. S. \& R. J. Whitley, 2008. Seasonal and pandemic influenza: A 2007 update on challenges and solutions. Clinical Infectious Diseases, 46, 1024-1031.

Munyua, P., C. Onyango, L. Mwasi, L. W. Waiboci, G. Arunga, B. Fields, A. M. Joshua, J. C. Cardona, P. Kitala, P. N. Nyaga \& M. K. Njenga, 2018. Identification and characterization of influenza A viruses in selected domestic animals in Kenya, 2010-2012. PLOS ONE 13, e0192721.

Olsen, B., V. J. Munster, A. Wallensten, J. Waldenstrom, A. D. Osterhaus \& R. A. Fouchier, 2006. Global patterns of influenza a virus in wild birds. Science, $\mathbf{3 1 2}$, 384-388.

Pittman, M., A. Laddomada, R. Freigofas, V. Piazza, A. Brouw \& I. H. Brown, 2007. Surveillance, prevention, and disease management of avian influenza in the European Union. Journal of Wildlife Diseases, 43, S64-S70.

Saldan, I. P., L. A. Chevtaeva, N. A. Razumovskaia \& O. A. Merkushev, 2006. Avian flu in Altay territory. Zhurnal Mikrobiologii, Epidemiologii, i Immunobiologii, 5, 104-105 (RU).
Schultsz, C., N. V. Dung, L. T. Hai, D. Q. Ha, J. S. M. Peiris, W. Lim, J. M. Garcia, N. D. Tho, N. T. H. Lan, H. H. Tho, P. X. Thao, H. R. van Doorn, N. V. V. Chau, J. Farrar \& M. D. de Jong, 2009. Prevalence of antibodies against avian influenza $\mathrm{A}(\mathrm{H} 5 \mathrm{~N} 1)$ virus among cullers and poultry workers in Ho Chi Minh City, 2005. PLOS ONE, 4, e7948.

Shortridge, K. F., N. N. Zhou, Y. Guan, P. Gao, T. Ito, Y. Kawaoka, S. Kodihalli, S. Krauss, D. Markwell, K. G. Murti, M. Norwood, D. Senne, L. Sims, A. Takada \& R. G. Webster, 1998. Characterization of avian H5N1 influenza viruses from poultry in Hong Kong. Virology, 252, 331-342.

Spackman, E., D. L. Suarez \& D. A. Senne, 2008. Avian influenza diagnostics and surveillance methods. In: Avian Influenza, ed D. E. Swayne, Blackwell Publishing, Ames, Iowa, pp. 299- 308.

Starick, E., O. Werner, H. Schirrmeier, B. Köllner, R. Riebe \& E. Mundt, 2006. Establishment of a competitive ELISA (cELISA) system for the detection of influenza A virus nucleoprotein antibodies and its application to field sera from different species. Journal of Veterinary Medicine. $B$, Infectious Diseases and Veterinary Public Health, 53, 370.

Trampel, D. W., E. M. Zhou, K. J. Yoon \& K. J. Koehler, 2006. Detection of antibodies in serum and egg yolk following infection of chickens with an H6N2 avian influenza virus. Journal of Veterinary Diagnostic Investigation, 18, 437-442.

Webster, R. G., M. Peiris, H. Chen, Y. Guan, 2006. H5N1 outbreaks and enzootic influenza. Emerging Infectious Diseases, 12, 3 8.

WHO, 2008. WHO/OIE/FAO H5N1 Evolution working group. Towards a unified nomenclature system for the highly pathogenic avian influenza $\mathrm{H} 5 \mathrm{~N} 1$ viruses. Emerging Infectious Diseases, 14, e1.

WHO, 2015. Cumulative number of confirmed human cases of avian influenza A (H5N1) reported to WHO. http://www. 
Serological survey for avian influenza virus infection of backyard poultry and poultry workers in ...

who.int/influenza/human_animal_interface /H5N1_cumulative_table_archives/en/ (Date last accessed 11 February 2019).

Wilson, H. M., J. S. Hall, P. L. Flint, J. C. Franson, C. R. Ely, J. A. Schmutz \& M. D. Samuel, 2013. High seroprevalence of antibodies to avian influenza viruses among wild waterfowl in Alaska: Implications for surveillance. PLOS ONE, 8, e58308.

Zhou, L., Q. Liao, L. Dong, Y. Huai \& T. Bai, 2009. Risk factors for human illness with avian influenza A (H5N1) virus infection in China. Journal of Infectious Diseases, 199, 1726-1734.
Paper received 19.09.2018; accepted for publication 18.01.2019

\section{Correspondence:}

Dr.Hazim Talib Thwiny

Department of Microbiology,

College of Veterinary Medicine,

University of Basrah,

Basrah, Iraq

e-mail: hazimthwiny@gmail.com 